\title{
Law Applicable to National Parks and Other Federal Reservations Within a State
}

$\mathrm{M}^{\mathrm{UCH}}$ was said during the last political campaign in commiserafound several of him recently in the national parks and military reservations. Having had occasion some years ago to acquire a small cabin site in a tract of patented land lying within the boundaries of General Grant National Park in California, and in consequence having been drawn into conversation in the local improvement club concerning questions of sanitation, water supply, policing, etc., I have discovered the original "No Man's Land" and the forgotten man.

In case of an automobile accident within a national park, what law governs, and in what court shall redress be sought? How can private property within the park be attached for debt or sold upon execution? Do state mechanics' lien laws and workmen's compensation acts apply therein? May lot owners in such park form a municipal corporation or a water or sanitary district? To what law should one look to define and punish criminal offenses? These are only some of the many questions which arise.

Primarily, federal reservations within a state may be classified according to their purposes and the nature of the governmental authority exercised within them. As to their purpose, such reservations may be (1) military, (2) federal buildings, (3) national parks and national monuments, (4) national forests and United States public lands generally, or (5) Indian reservations. ${ }^{1}$

From the standpoint of political authority and jurisdiction, such reservations may be classified as: (1) lands owned by the federal government over which exclusive jurisdiction has been ceded by the state, (2) public office buildings and grounds actually devoted to the carrying on of a federal function but without a cession of exclusive jurisdiction by the state, (3) lands within the state owned by the federal government but held merely in a proprietary capacity, such as public lands.

In all federal reservations the status of persons temporarily or permanently resident therein may be that of (1) officer or employee of the United States in military or civilian occupation, (2) private per-

1 The District of Columbia and the territories and possessions of the United States involve different situations not here considered. 
son residing on government land within the reservation, concessionaire, visitor, camper, etc., or (3) owner of private lands located within the boundaries of the reservation.

In the District of Columbia, which was ceded by Maryland to the United States for its seat of government, the federal government has exclusive jurisdiction and governmental powers both from express grant in the Constitution and from Maryland's act of cession. Maryland retains no authority, civil, criminal or judicial, to apply its laws or processes to persons or transactions within the District.

Similarly, but without express constitutional authorization, it has been customary, in the case of many federal reservations created within a state subsequent to its admission to statehood, for the state to cede to the United States exclusive jurisdiction over the tract and for Congress to accept such exclusive jurisdiction. Where this is done the reservation assumes a status comparable to that of the District of Columbia, except that the federal government has usually failed to create or specify the law applicable to private persons within the area.

In the case of public buildings and grounds devoted to the performance of federal functions, but without cession of jurisdiction by the state, state laws and jurisdiction still apply, with the important qualification that the state cannot in any manner obstruct or interfere with the execution of federal activities. This results in a concurrent jurisdiction with federal authority predominating.

Where a federal reservation is created within a state after its admission to statehood, and the state does not cede exclusive jurisdiction to the United States, the position of the latter is merely that of a private proprietor of the lands owned or leased by it within the reservation. The power to govern, with relation to both public and private lands, remains in the state, with the exception that the state cannot interfere with the use of such lands for federal purposes, nor with the discharge of lawful activities by the federal officers stationed in such reservations.

By a statute of California passed in 1919 the state ceded to the United States Government exclusive jurisdiction over the lands then or thereafter included within Yosemite, Sequoia and General Grant National Parks, with certain reservations. ${ }^{2}$ This grant of exclusive jurisdiction was accepted by Congress with the same reservations. ${ }^{3}$

2 Cal. Stats. 1919, p. 74, c. 51. See page 155 , infra.

341 STar. (1920) 731, 16 U. S. C. (1926) \$57.

General Grant National Park was created long after the admission of California to stateliood. At the time of its creation by an act of Congress, parts of the land within the park were United States public lands. A portion containing a 
I. WHEN DOES EXCLUSIVE FEDERAL JURISDICTION OVER LAND

WITHIN STATE ATTACE?

Land within a state may become subject to the exclusive jurisdiction of the United States Government in one of several ways:

(a) By reservation of jurisdiction over specified public lands in the enabling act admitting the state to the Union.

Since the act of admission to statehood is in effect a cession of exclusive jurisdiction and sovereignty by the United States to the people of the newly-created state, the former may except from the cession such portions of its former sovereignty as may be needed for the future discharge of federal functions with respect to tracts of land devoted to federal purposes. ${ }^{4}$

(b) By a purchase of land within the state subsequent to its admission to statehood, with the consent of the state, under section 8 of article I of the United States Constitution, which reads in part as follows: "The Congress shall have power ... (17) to exercise exclusive legislation in all cases whatsoever, over such District [District of Columbia] .... and to exercise like authority over all places purchased by the consent of the legislature of the state in which the same shall be, for the erection of forts, magazines, arsenals, dock yards, and other needful buildings." 5

Where this section has been strictly complied with in obtaining the consent of the state legislature to the purchase, the United States enjoys exclusive jurisdiction over such lands by virtue of the Constitution itself. The provision has, however, been strictly construed. The land must be purchased by the United States after the admission of the state to statehood. ${ }^{6}$

noteworthy grove of Sequoia Giganted trees, then held in private ownership, was conveyed by its owners to the government. Other land within the park boundaries which was then held in private ownership has so remained to the present time and has recently heen subdivided and sold in fee simple to summer campers for cabin lots. The administration of affairs within the park is entrusted by act of Congress (16 U. S. C. (1926) $\S \S 1-77)$, to the National Park Service, a branch of the Department of the Interior.

4 Benson v. United States (1892) 146 U. S. 325 (Fort Leavenworth military reservation).

5 Itahics added.

6 Williams v. Arlington Hotel Co. (E. D. Ark. 1926) 15 F. (2d) 412, rev'd, (C. C. A. 8th, 1927) 22 F. (2d) 669 ; St. Louis-San Francisco Ry. v. Satterfield (C. C. A. 8th, 1928) 27 F. (2d) 586 . A cession by the state instead of a purchase from private citizens with the consent of the state is insufficient to invoke the constitutional authority. Crook, Horner \& Co. v. Old Point Comfort Hotel Co. (C. C. E. D. Va. 1893) 54 Fed. 604. The land must be acquired for the purposes specified in Article I, section 8 of the Constitution. In re Kelly (C. C. E. D. Wis. 1895) 71 Fed. 545. 
(c) By a cession of exclusive jurisdiction by the state to the United States, accepted by Congress.

It was at first contended that a state could not constitutionally cede away any portion of its sovereignty or jurisdiction, and hence could not validly cede to the United States exclusive jurisdiction over any lands within its boundaries. It is now settled, however, that a state may in any case cede exclusive jurisdiction over lands within it to the United States, but may not cede lands or jurisdiction to a foreign country. ${ }^{7}$

Such cession is, however, valid only if the land is to be used for purposes of the federal government. A national park has been held to be within such classification. ${ }^{8}$

The state may also attach reservations to its cession. In the case of the Yosemite, Sequoia and General Grant National Parks in California, reservations were incorporated by the state in its act of cession and accepted by Congress, as follows: (a) That private property and franchises within the park should remain taxable by the state, and fishing licenses be collectible by it. (b) That permanent residents within the parks may vote at state elections. (c) That civil and criminal processes of the state courts as to transactions occurring outside of the park may be served upon persons within such park.

In all other cases state jurisdiction remains in force over all persons and property within the federal reservation, except as noted immediately below.

\section{FEDERAL RESERVATIONS WITHIN STATE IN WHICH FEDERAL GOVERNMENT DOES NOT HAVE EXCLUSIVE JURISDICTION}

In this case the United States stands in the position of a private proprietor only of its public lands within the reservation, except that its right to regulate the use and disposition of its lands and to carry out any federal functions to which the lands may be applied, cannot be interfered with by the state. All other governmental powers, such as the government of persons and transactions not involving federal administration, remain with the state.

For instance, the criminal laws of the state govern such reservation to the same extent as other parts of the state. Persons charged with

7 Benson v. United States, supra note 4; Arlington Hotel Co. v. Fant (1929) 278 U. S. 439.

8 United States v. Gettysburg Electric Ry. (1896) 160 U. S. 668. 
crime are prosecuted and punished in the state courts. ${ }^{\ominus}$ In civil matters the rule is the same..$^{10}$

Interesting questions have arisen as to the applicability of state laws, such as those pertaining to fencing and grazing, to United States public lands and as to the validity of federal regulations concerning the use of such public lands. It is settled that the United States as proprietor may regulate and protect the use of public lands within a state. $^{11}$ It may direct its forest rangers to kill off surplus deer in a national forest and gaine reserve where such deer are starving or are damaging trees, bushes and shrubs, even though the game laws of the state in which such public lands are located may prohibit the killing of such deer. ${ }^{12}$ It may punish the unlawful occupancy of United States public lands within a state, ${ }^{13}$ and prohibit the grazing of stock on such lands except under permit of the Secretary of the Interior. ${ }^{14}$

The state may enforce its game laws over United States public lands where not in conflict with federal regulation respecting their use. It may regulate the grazing of cattle and sheep on such lands subject to the same limitation. ${ }^{15}$

Over private holdings within such federal parks and reservations, the United States has no proprietary functions, nor does it possess any governmental powers beyond the extent to which the federal laws may apply to residents of the state outside such federal reservation. The United States cannot deprive such landowner of the beneficial use of his lands within the reservation or substantially restrict him in such use. $^{10}$ This was ruled upon in Curtin v. Benson. ${ }^{17}$

When Curtin v. Benson was decided, exclusive jurisdiction had not been ceded to the United States over Yosemite National Park. Curtin desired to bring cattle over park roads to patented lands owned by him within the park. The park regulations prescribed by the Secretary of the Interior provided that owners of patented lands could bring

${ }^{9}$ McKelvey v. United States (1922) 260 U. S. 353; Pothier v. Rodman (C. C. A. 1st, 1923) 291 Fed. 311 (murder on military reservation); United States v. Bateman (C. C. N. D. Cal. 1888) 34 Fed. 86 (nuurder at San Francisco presidio); In re Kelly, supra note 6; In re O'Connor (1875) 37 Wis. 379.

10 Hoffman v. Leavenworth Light \& Power Co. (1914) 91 Kan. 450, 138 Pac. 632 (action for wrongful death under state statute).

11 U. S. Consr., Art. IV, \$3.

12 United States v. Hunt (D. Ariz. 1927) 19 F. (2d) 634.

13 Canifield v. United States (1897) 167 U. S. 518.

14 United States v. Grimaud (1911) 220 U. S. 506; Light v. United States (1911) 220 U. S. 523.

15 Onıechevarria v. Idaho (1918) 246 U. S. 343.

16 Curtin v. Benson (1911) 222 U. S. 78; Colorado v. Toll (1925) 268 U. S. 228.

17 Supra note 16. 
in their cattle only under written consent of the park superintendent and that where such patented lands were unfenced, their metes and bounds must be designated so that the lands might be distinguished from park lands. As a result of a dispute between the park superintendent and Curtin over the boundaries of the latter's land, which was unfenced, the superintendent excluded Curtin's cattle upon the ground that he had not complied with park regulations. It was held by the United States Supreme Court that the superintendent's action constituted an illegal restraint upon Curtin's right to full enjoyment of his patented lands and his right of access thereto. Such property rights cannot be substantially restricted or infringed by federal authorities.

In Colorado v. Toll ${ }^{18}$ the superintendent of the Rocky Mountain National Park attempted to enforce park regulations restricting the carrying of passengers for hire over park roads and imposing a license fee for automobile stage service. The State of Colorado had not then ceded exclusive jurisdiction over the park lands and much of them was held in private ownership. It was decided that under these circumstances the federal government had no authority to limit or regulate the business of private persons on private lands within the park, or to regulate licenses or to grant a monopoly of auto transportation over the park roads. Such power of regulation, if it existed, was in the state and not in the federal government.

Probably, however, private landowners within such reservation are not wholly immune from reasonable federal regulations designed to protect the park or reservation.

III. FEDERAL RESERVATIONS WITHIN STATE WHERE EXCLUSIVE JURISDICTION EXISTS IN FEDERAL GOVERNMIENT

Where the federal government possesses exclusive jurisdiction over a federal reservation within a state its power to govern persons residmg within the park and to fix their legal rights and duties is absolute. For governmental purposes the park is as much subject to exclusive federal control, notwithstanding the fact that it lies wholly within a state, as is the District of Columbia or the Territory of Alaska. The only question is as to the law prevailing within such reservation, particularly as Congress has not made provision for municipal law or civil government therein.

A. Criminal Law. In the field of criminal law Congress has made the most adequate provision. It has specifically enacted that all laws applicable to places within the sole and exclusive jurisdiction of the

18 Supre note 16. 
United States shall apply to national parks. ${ }^{19}$ This brings into force the federal criminal code which applies to crimes committed on American vessels upon the high seas, on military reservations, in the District of Columbia, etc. ${ }^{20}$

Necessarily, also, all federal penal laws applicable within the states, as for the prevention of counterfeiting, violation of postal regulations, treason, etc., are equally applicable in such parks and reservations.

The Assimilative Crimes Act, applying to the three national parks in California above mentioned, provides that if any offense shall be committed within such national parks "which offense is not prohibited or the punishment is not specifically provided for by any law of the United States, the offender shall be subject to the same punishment as the laws of the State of California in force at the time of the commission of the offense may provide for a like offense in said State; and no subsequent repeal of any such law of the State of California sliall affect any prosecution for such offense committed within said parks. . .."21

The effect of the present general congressional act adopting state criminal statutes in federal reservations is now to make applicable all state statutes enacted prior to and in force on June 1, 1933..22 Notwithstanding possibly divergent language of Title 16, section 59 to the contrary, the Assimilative Crimes Act adopts only those state statutes in force at the time of its passage. ${ }^{23}$ Successive reënactments of the federal provision from time to time in the course of codification of the federal statutes or otherwise bring into force new state legislation enacted in the meantime. ${ }^{24}$

Difficulty may be encountered in the application of certain regulatory penal statutes in national parks. For instance, state liquor license

1941 STAT. (1920) 731, 16 U. S. C. (1926) $\$ 58$.

20 Prosecutions under the federal criminal code for crimes committed within such reservations are illustrated in Battle v. United States (1908) 209 U. S. 36; Umited States v. Unzeuta (1930) 281 U. S. 138; United States v. Watkins (N. D. Cal. 1927) 22 F. (2d) $43 \%$.

2141 Star. (1920) 731, 16 U. S. C. (1926) \$59. See parallel enactment 35 StaT. (1909) 1145,18 U. S. C. (1926) \$468 (U. S. CRIM. CODE §289) applying to all places under exclusive jurisdiction of United States.

An interesting prosecution under a state criminal statute made applicable by the Assimilative Crimes Act is found in Burns v. United States (1927) 274 U. S. 328 (violation of California Criminal Syndicalism Act, committed in Yosemite National Park).

2241 STaT. (1920) 731, 16 U. S. C. (1926) \$59; 35 STAT. (1909) 1145, 18 U. S. C. (1926) $\$ 468$ (U. S. CrTor. CODE $\$ 289$ ) as amended by act approved June 15, 1933, 48 Stat. 152, 18 U. S. C. (1933) \$468.

23 United States v. Paul (1832) 6 Pet. (31 U. S.) 141; Franklin v. United States (1910) 216 U. S. 559.

24 United States v. Tucker (W. D. Ky. 1903) 122 Fed. 518. 
laws have been held inapplicable to federal reservations. ${ }^{25}$ State fencing acts have been likewise held inapplicable. ${ }^{26}$

Jurisdiction of prosecutions for offenses committed within such federal reservations, whether under a federal penal statute or state statute made applicable by the Assimilative Crimes Act, is exclusively in the federal courts, or before the proper federal commissioner appointed for the park under the authority of Title 16, section 66 of the United States Code. State courts have no jurisdiction over such offenses. ${ }^{27}$ Thus where a prosecution was instituted before a justice of the peace of Tulare County, California, charging the defendant with non-payment of laborers' wages for work done within General Grant National Park, under the state labor laws, an injunction was granted by the United States District Court to restrain such prosecution upon the ground that the state courts had no jurisdiction. ${ }^{28}$

B. Civil Law. In matters involving private rights and duties of a civil nature, such as contract, tort and property rights, the situation is more obscure. It is difficult to find any applicable body of law of suffcient extent to provide adequately for the many questions which continually arise.

(1) Possible Sources of Private Law. Possible sources of a private municipal law which may apply in such federal reservations are federal statutes, federal common law, state statutes, state common law, a general common law, national park service regulations, and local laws enacted by the residents of such parks. These will be discussed below.

Federal Statutes: While complete power rests in Congress to prescribe the law which shall apply, Congress has not expressly created for or extended to national parks and other federal reservations any body of civil law. The nearest approach is found in Title 16, section 58 of the United States Code, which provides that all laws applicable to places under the sole and exclusive jurisdiction of the United States shall have force and effect in the three national parks therein specified. Does this provision, refer to civil law, or only to federal criminal statutes? Does it make apphicable in General Grant Park the local law of the District of Columbia, of the Territory of Hawaii, of the Territory of Alaska, of the Panama Canal Zone? Would a marriage be valid if performed in the park without a license issued in the District of Columbia? Does the Building Code or the Motor Vehicle Act of the Dis-

${ }^{25}$ In re Ladd (C. C. D. Neb. 1896) 74 Fed. 31; Commonwealth v. Clary (1811) 8 Mass. 72.

26 Anderson v. Chicago \& N. W. Ry. (1918) 102 Neb. 578, 168 N. W. 196.

27 In re Ladd, supra note 25.

${ }^{28}$ Ferguson v. McCormick (D. Cal. unreported). 
trict of Columbia apply? All that can be said is that no decided case has yet held the body of law of any other federal district or territory to be applicable to the national parks under section 58.20

The situation in national parks may be contrasted with that illustrated in Biddle v. United States, ${ }^{30}$ involving the rules of law to be applied in the United States Consular Court for China. The act of 1906, supplementing the act of 1901 creating that court, provided that the treaties and laws of the United States should furnish the rule for decision, and, where deficient, the common law decisions of the United States courts and the law of admiralty and equity should apply.

Federal Common Law: It is generally understood that there is no federal common law applicable without statutory authority to places under the exclusive jurisdiction of the United States.

State Statutes: The states have no power to apply the acts of their legislatures to territory within their boundaries which is subject to the exclusive jurisdiction of the United States. Several state statutes of a civil nature enacted after the cession of jurisdiction to the federal government have been declared to be without binding force. ${ }^{31}$

On the other hand, it has been held in a number of cases cited elsewhere in this article, that the statutory law of the state in force at the time of cession remains in force thereafter in the federal reservation until abrogated by Congress. Even a later repeal by the state of such statute will not repeal it within the federal reservation. ${ }^{32}$ While this seems to provide some body of local law for the government of persons in national parks, it is hopelessly impossible of application to modern conditions. To expose the residents of the Brooklyn Navy Yard to the New York statutory law existing before 1853, as was done in McCarthy v. Packard Co., 33 without the benefit of statutory changes subsequent to that date, is an anachronism. The only saving grace is that the number of transactions within federal reservations which give rise to legal rights and obligations is relatively small.

29 The possibility of their application is further negatived by such cases as Crook, Horner \& Co. v. Old Point Comfort Hotel Co., supra note 6; In re Ladd, supra note 25; Kaufinan v. Hopper (1917) 220 N. X. 184, 115 N. E. 470 . Section 58 does not purport to extend to national parks the common law, equity or admiralty law.

30 (C. C. A. 9th, 1907) 156 Fed. 759.

31 Arlington Hotel Co. v. Fant, supra note 6; Commonwealth v. Clary, supra note 25; Mitchell v. Tibbets (Mass. 1835) 17 Pick. 298; Barrett v. Palmer (1892) 135 N. Y. 336, 31 N. E. 1017, af'd, (1896) 162 U. S. 399; McCarthy v. Packard Co. (1905) 182 N. Y. 555, 75 N. E. 1130, af'g (1905) 105 App. Div. 436, 94 N. Y. Supp. 203; Farley v. Sherno (1913) 208 N. Y. 269, 101 N. E. 891; Kaufman v. Hopper, supra note 29.

32 McCarthy v. Packard Co., supra note 31.

33 Ibid. 
State Common Law: In common law states, it might be arguable that the court should adopt the common law rules in force in the territory immediately surrounding the federal reservation, for want of any other system of law. Occasionally this course is followed in other fields by the courts, as pointed out below. Such practice would not help the problem in General Grant and nearby national parks and reservations, however, as California is not a common law state. Its substantive law, including its codes, is fundamentally statutory.

General Common Law: There is an occasional intimation in American constitutional cases of a resort, for want of a definite binding law to fit the case, to a generalized, omnipresent and inchoate common law. Such common law is not the actual law in force in any particular state, but a sort of jus gentium, a composite of those rules and customs of general acceptance in American jurisprudence. Our admiralty law has been largely built up by adoption of such common law rules. ${ }^{34}$ It is conceivable that a court might resort to such general principles in cases arising in federal reservations and parks, for want of a more definite binding law. Cases cannot be left undecided for want of an applicable law.

Nevertheless, this solution can never be applied except interstitially, i.e., to fill a void where no other applicable law can be found. As the growth of modern statutory law has weakened the force and reduced the field of common law, resort to such common law would not now be adequate to meet human needs. Questions of property, tort, employers' liability, mortgages, liens and other matters commonly encountered are now largely governed iby statutory rules involving descent, probate, motor vehicles, statutory negligence, workmen's compensation, recording acts, uniform sales, mortgage and other commercial statutes, etc.

Local Legislation Enacted by Park Residents: If the residents of national parks or federal reservations couldıorganize municipal corporations, water, sanitary and school districts, etc., and legislate to provide police and fire protection and local courts, similar to the local government of an organized territory of Ithe United States, most of the gaps in the law would disappear. But such public or quasi-public corporations cannot be validly created under state law, and Congress has provided no machinery for their creation. .

Owing also to the peculiar nature of such federal reservations, congressional authority would be impracticable. Private permanent residents who could qualify as voters are few in number, 1 most of the users

34 The Osceola (1903) 189 U. S. 158; Southern Pacific Co. v. Jensen (1917) 244 U. S. 205; Pillsbury, Jurisdiction Over Injuries to Maritime Workers (1932) 18 VA. L. REv. 740. 
of the parks being summer occupants or persons in federal service. The private holdings are usually not extensive, and the physical needs of residents which icannot be supplied by the park service or military control of the reservation, if an army post, are small in proportion to the preponderant federal functions for which the reservation was created.

National Park'Service Regulations: Title 16, section 61 of the United IStates Code provides that the Secretary of the Interior may make and publish such general rules and regulations as he may deem necessary and proper for the management and care of the park and for the protection and care of the property therein, animals iand fish, and for the conservation of the scenery and natural and historic objects, etc. Violation of such regulations is made a misdemeanor by section 3, and punishable 1 by fine or imprisonment.

The validity of park regulations by the Secretary of the Interior and of punishments imposed for their violation, luas been upheld..$^{35}$

The scope to which the present statutory powers of the Secretary of the Interior can be extended in providing necessary local government for temporary and permanent residents in a national park is quite restricted. It would seem, however, that regulations for the safety and health of park visitors and residents, good order in the park, Ifire prevention, etc., are included within the present authority. The primary purposes for which national parks and the park service were created would not be iaccomplished unless the power to make regulations for the health and safety of park visitors and residents exists. It would seem, therefore, that lawful regulations can be made concerning such matters as sanitation, fire protection, higlwway regulations, etc., as an incident.to the management of the park. For instance, open privies can be prohibited and other nuisances stopped. Such regulations, when made, are binding alike on private landowners, concessionaires and visitors within the park, as the power of the federal government is supreme.

(2) Special Problems. A few specific transactions involving private rights and duties in the national parks or other federal reservations have received the attention of the courts. While insufficient in extent to-solve the entire problem of the law governing private rights in such areas, they are illustrative of the difficulties presented.

Personal Injuries. The generally accepted view as to the law applicable to personal injuries is that the law of the state in effect at the

35 Robbins v. United States (C. C. A. 8 th, 1922) 284 Fed. 39 (regulating use of highway within park and forbidding carrying of passengers for hire without permission of Park Service). 
time of cession by the state must be applied. Later statutory modifications by the state are not applicable. ${ }^{36}$

In Hoffman v. Leavenworth Light \& Power Co. ${ }^{37}$ a different view was adopted. It was there intimated that the state in whicli the reservation lay -retained some legislative power to regulate private riglits, where sucli regulation would not be inconsistent with federal law and the exercise of federal functions in the reservation. The decision was based upon a misunderstanding of the decisions of the United States Supreme Court in Fort Leavenworth $R . R$. v. Lowe $e^{38}$ and Chicago, $R$. I. \& P. Ry. v. McGlinn. ${ }^{39}$ The Supreme Court subsequently corrected such misinterpretation by its decision in Arlington Hotel Co. v. Fant. ${ }^{40}$

It is submitted, nevertheless, that the Hoffman decision is riglt in result and.can be justified in principle, althougli upon a different theory. It is not sufficient that a given result be supported by correct legal reasoning. Law is made for persons, and not persons for legal theory. The result of any legal reasoning must be.in accord with public policy and human needs. If it is not, a different theory must be wrought, which will accomplish sound public policy.

In the cases involving personal injuries, it was easy to fall into error. From the time of cession of jurisdiction by the states over Fort Leavenworth and the Brooklyn Navy Yard, involved in the above cases, until after these cases arose, the law of personal injuries did not change greatly. An analogy was made to the undoubted doctrine of international law that the private law of ceded territory remains in force after cession until changed by authority of the new sovereign. The court also referred to the well-established doctrine that the former sovereign

36 Steele v. Halligan (W. D. Wash. 1916) 229 Fed. 1011 (laws of state in effect at time of cession renrain in force as laws of United States until changed by Congress); Danielson v. Donmopray (D. Wyo. 1932) 57 F. (2d) 565 (death statute of Wyoming in effect before cession of jurisdiction applied); McCarthy v. Packard Co. (state death statute in effect at time of cession applied, notwithstanding later repeal by state before cause of action arose); Farley v. Scherno, both supra note 31; Kaufman v. Hopper, supra note 29 (New York scaffolding act refused application in determining negligence of defendant, as enacted after cession. New York common law and statutes in effect at time of cession apphed.)

For application of a state Workmen's Compensation Act to a federal military reservation, see Kaufman v. Hopper, supra note 29; Cameron v. Ellis Const. Co. (1930) 252 N. Y. 394, 169 N. E. 622; Walsh v. Apartment Engineering \& Contracting Co. (App. Div. N. Y. 1933, not yet reported).

37 Supra note 10.

38 (1885) 114 U. S. 525.

39 (1885) 114 U. S. 542 (criminal case).

40 Supra note 7. The same error was made in Crook, Horner \& Co. v. Old Point Comfort Hotel Co., supra note 6 (mechanic's lien) which was likewise overruled in Arlington Hotel Co. v. Fant. 
can retain no legislative power over ceded territory after its cession to another.

The subsequent course of events has shown that other vital factors were overlooked, chiefly because they became important at a later date; yet the earlier decisions have since been followed to unjustifiable results upon the theory of stare decisis. In later years we have seen the common law rules of employers' liability superseded by workmen's compensation acts. Other rules of liability for negligence have been altered, such as the creation of negligence per se in many instances. An entire new body of law has grown up around automobiles, and state motor vehicle acts now prescribe exclusively the rule and measure of liability in the largest simgle class of personal injuries litigated today.

The bulk of the law of personal imjuries in effect at the time of cession of the various federal reservations is therefore now archaic and obsolete. It is also inpossible for persons, such as automobile tourists, passing from state to federal territory or going through federal reservations to familiarize themselves with the older rules of law assumed to remain in force in the federal reservations. Even the park and reservation administrators, the lawyers and courts probably do not now remember the laws as they stood at the date of cession.

The required result can be obtained by recourse to a principle already sanctioned by the courts in other instances, i.e., that where there is a void in a body of federal law, the appropriate state law, when not inapplicable or inconsistent with federal law, may be adopted by the courts as federal law. This course has been followed by our courts from the beginning with respect to the common law. Where a body of federal law contained no provision upon a particular subject, the common law has been applied without hesitation. As there is no federal common law, necessarily the common law of the states has been adopted.41

State statutes have also been adopted in the same fashion. The maritime law of the Umited States did not, prior to 1920, contain a provision for damages for wrongful death. The admiralty courts of the United States therefore adopted and applied the death statute of the state in which the tort occurred, as the measure of liability in each case of wrongful death. ${ }^{42}$

Adoption of this practice in personal injury and similar cases arising in national parks and other federal reservations is suggested, until such time as Congress shall provide for a different rule. Congress should

41 Pillsbury, loc. cit. supra note 34.

42 See cases cited in dissenting opinion of Brandeis, J., in Southern Pacific Co. v. Jensen, supra note 34 . 
provide, as it did by the Assimilative Crimes Act, for the adoption of the law of the state as federal law for the federal reservations within the borders of such state, where not inapplicable or inconsistent with existing federal law or functions.

Injurics to Personal Property. As a result of the destruction by fire of a hotel at Hot Springs, Arkansas, located in a military reservation over which the state had ceded exclusive jurisdiction to the United States, two actions were filed by guests for loss of personal property. In each, the hotel depended upon a recent state statute, passed subsequent to the .cession, limiting the liability of imnkeepers. In the first action, Williams v. Arlington Hotel Co., ${ }^{43}$ the district court applied the state statute upon the theory that the federal government had abandoned its jurisdiction by leasing the land for private use, and ceasing to use it for military purposes. This was reversed by the circuit court of appeals, holding that there was no abandonment and the state act was inapplicable. ${ }^{44}$

In Arlington Hotel Co. v. Fant, the same issues were raised and carried eventually to the United States Supreme Court. It was held by that court that exclusive federal jurisdiction had not been lost. The state statute was held inapplicable as the state retained no legislative authority after cession.

Mechanics' Liens. In Crook, Horner \& Co. v. Old Point Comfort Hotel Co., ${ }^{45}$ a private corporation operating a hotel on the military reservation of Fortress Monroe, Virginia, was sued under the Virginia inechanic's lien law for goods and labor furnished. The circuit court applied the state statute, stating that the statutes of Virginia, passed after the cession, apply unless incompatible with United States laws affecting the territory or unless they interfere wth the exercise of federal functions therem. This decision is doubtless overruled by the later decision of the Supreme Court in Arlington Hotel Co. v. Fant. Nevertheless, if private hotels, stores or houses are to be built on public or private lands in national parks and reservations, there must be some provision for innkeepers' liens, mechanics' liens, conveyances, incuinbrances, recording of deeds, mortgages, deeds of trust, chattel mortgages, bulk sales, foreclosures, attachments, executions, lis pendens, wage claims, priorities, conditional sales, and the multitude of legal rights and remedies which are necessary and in constant use in modern commercial transactions of all sorts. The federal law does not supply these necessary provisions. It is suggested that the commercial and

43 Supra note 6.

44 Ibid.

45 Supra note 6. 
property law of the state in which the federal reservation or park is situated, should be adopted by the courts, where not inconsistent, as part of the federal law of the territory for the time, being.

State Taxation of Private Property in National Park. A clearer situation is, that presented by the taxation of private property in national parks by the state. The power to tax is an' attribute of sovereignty. As the state surrenders its entire sovereignty over the national park or other federal reservation in ceding exclusive jurisdiction to the United States, it naturally follows that it can no longer tax private property within the territory ceded. Where, however, the state in its act of cession has, reserved the power to tax private property, and jurisdiction has been accepted by Congress subject to such reservation, the power of taxation remains in the state. ${ }^{46}$

Regulation of Alcoholic Liquors. With the repeal of the 18th Amendment, the question of the power of regulation of the sale and use of intoxicating liquors within national parks and other federal reservations deserves attention. It is important that the national parks do not become wet oases in dry states, and also that they be properly policed to prevent drunkenness, accident and crime through improper use of private buildings in the parks.

Cases decided on this subject are confined to holding that state and local laws licensing the sale of alcoholic liquors are of , no force within federal reservations. ${ }^{47}$

In re $\operatorname{Ladd}^{48}$ is also authority for the proposition that certain state liquor laws, although in force prior to the cession of jurisdiction over the military reservation there involved, were not applicable as they were inconsistent with federal rules and regulations respecting sales of liquor at army posts, and therefore not adopted by the United States.

It is difficult to see how a state liquor licensing system can be made applicable to a federal reservation under the Assimilative Crimes Acts, as the criminal penalties provided for the sale of liquor without a license do not partake purely of the nature of punishment for crime. They are rather provisions in aid of regulatory and tax measures, and depend upon the validity of the regulatory and tax features of the law.

It is conceivable that a state liquor law which is wholly prohibitory and penal might be enforced in a national park, if the prosecution were in the federal courts or before the proper federal commissioners. In such cases, however, the question must be considered whether the state

46 Surplus Trading Co. v. Cook (1930) 281 U. S. 647 (Camp Pike, Arkansas).

47 Commonwealth v. Clary; In re Ladd, both supra note 25 .

48 Ibid. State acts providing civil penalties do not apply in such reservations. Western Union Tel. Co. v. Chiles (1909) 214 U. S. 274. 
law is inconsistent with federal statutes or the lawful regulations of the federal agency in charge of the particular reservation. In re Ladd involved the sale of liquor at an army canteen in a military reservation in Nebraska, such sale being in accordance with army regulations then existing.

Substantially, state liquor laws can have little or no validity in a national park or other reservation. The,state certainly has no power of enforcement. Any effective regulation must come from the federal government. The United States possesses all the power of government with respect to such reservations and parks. It is a mistake to assert that private landholders or other persons in such places are beyond the power of governmental control. The authority of the federal government as to them is no less than its power over private persons and property in the District of Columbia. It merely has not yet realized and exerted its powers.

In the absence of a specific act of Congress regulating, licensing or prohibiting the sale or possession of alcoholic liquors in the parks and reservations, recourse must be had, as the situation now stands, to the following sources of law or regulation in order: (1) the criminal code of the United States; (2) the Assimilative Crimes Acts for the different parks and reservations; (3) park service regulations, or their equivalent in other types of regulations.

As an emergency measure upon the repeal of the 18th Amendment, Congress should immediately prescribe regulations concerning the sale and use of intoxicating liquors in federal reservations, forts, public buildings, grounds and parks.

Residence and Domicile. Many interesting questions are suggested as to residence and domicile, most of which cannot be positively answered as yet. In Sinks $v$. Reese, ${ }^{49}$ it was held that the legislature of Ohio could not confer the right to vote in state elections upon officers, employees or inmates of a National Soldiers' Home in that state, over which exclusive jurisdiction had been ceded to the federal government, such persons not being residents of the State of Ohio. The Maryland court held in Lane v. Lane $e^{50}$ that residence on a federal reservation in that state, over which jurisdiction had been ceded, was not residence within the state so as to create jurisdiction for divorce. But in Divine v. Unaka National Bank, ${ }^{51}$ Tennessee held that residence in a soldiers' home over which jurisdiction had been ceded, constituted residence in

\footnotetext{
49 (1869) 19 Ohio St. 306.

50 (1926) 150 Md. 592, 133 Atl. 729.

51 (1911) 125 Tenn. 98, 140 S. W. 747.
} 
the state for the purpose of jurisdiction in probate and administration proceedings.

In Opinion of the Justices ${ }^{52}$ the Massachusetts court stated that residence in a federal reservation did not confer a right to the benefits of the common schools in the town in which such reservation was situated, to poor relief, nor the right to vote, nor create the obligation of paying taxes.

Miscellaneous. It would also seem that attachment or execution under process of state courts cannot be levied on property within a park. Probably mortgages on real estate within the park cannot be foreclosed by state court action.

The validity of a marriage solemnized within a national park is open to attack upon technical grounds, although probably the elements of public policy involved would lead a court to apply a general common law to save the situation. But if common law marriages are valid if contracted within a national park in California, would such marriages be recognized by our courts, although ordinarily a common law marriage cannot be contracted in California?

\section{CONCLUSION}

The present deplorable condition of the law applicable to national parks and other federal reservations within a state should not endure. Public rights are protected to some extent by the Assimilative Crimes Acts and other legislation. Private rights should be accorded as great, if not greater, protection. The obligations of the general government to citizens inhabiting these parts of the United States are as important as the obligation of any state government to its citizens. The relation of governing and governed is a reciprocal one, in which the latter yield obedience in return for protection of rights and redress of wrongs. The state of the law in federal reservations takes care of but a small portion of that relation. Congress has not intentionally determined that the present situation should exist as it is; rather the paucity of federal law applicable to such reservations is due to inattention upon the part of the national legislature. An inmediate amelioration of the condition is highly to be desired.

Warren H. Pillsbury.

San Francisco, Caltfornia.

52 (Mass. 1853) 1 Metc. 580. 